\title{
Environmentally sound Management of Ship Wastes: challenges and opportunities for European ports
}

\author{
Gabriela Argüello (1)
}

Correspondence: gabriela.arguello@ law.gu.se

Department of Law, School of Business Economic and Law at the University of Gothenburg, 40530 Gothenburg, Sweden

\begin{abstract}
Ship wastes are incidentally regulated within the regime of marine pollution and the prevention of ship-source pollution is heavily reliant on the provision of adequate port reception facilities on land. However, the coordination between these facilities and further downstream management operations is still an unresolved issue. This paper examines from a legal perspective the challenges and opportunities related to the management of wastes generated on-board vessels after they are discharged to port reception facilities. Ship wastes are studied from a European Union (EU) law perspective and the author evaluates the integration of ship waste management within wider EU waste legislation and national waste management plans.
\end{abstract}

Keywords: Ship wastes, Port reception facilities, Sea/land interface, Waste management, Directive (EU) 2019/883

\section{Introduction}

From a legal perspective, waste management has traditionally dealt with downstream disposal operations. A life-cycle approach, by contrast, offers a new perspective that involves every phase, i.e., from the prevention and reduction of waste generation to the actual handling of wastes. Waste handling includes the collection, transport, monitoring, and treatment (re-use, recycling, energy recovery, and final disposal, e.g. landfill) of wastes including the after-care of waste facilities. The main legal challenges of applying a life-cycle approach to waste management are twofold. First, waste management is regulated incidentally, i.e., within media-specific pollution regimes, e.g., sea, air, land-based pollution; or in relation to hazardous substances, e.g., regulation of persistent organic pollutants (POPs). In cases where wastes are directly regulated, this regulation is concerned with a particular activity, i.e., transboundary movements or dumping. The incidental regulation of wastes involves a risk of transfer of pollution from one environmental medium to another, resulting in fragmentation. Such fragmentation produces a lack of coordination between different regimes and the proliferation of conflicting and inconsistent legal obligations. The second challenge is that waste management has been traditionally considered as a national affair except in cases dealing with pollution transfer and

(c) The Author(s). 2020 Open Access This article is licensed under a Creative Commons Attribution 4.0 International License, which permits use, sharing, adaptation, distribution and reproduction in any medium or format, as long as you give appropriate credit to the original author(s) and the source, provide a link to the Creative Commons licence, and indicate if changes were made. The images or other third party material in this article are included in the article's Creative Commons licence, unless indicated otherwise in a credit line to the material. If material is not included in the article's Creative Commons licence and your intended use is not permitted by statutory regulation or exceeds the permitted use, you will need to obtain permission directly from the copyright holder. To view a copy of this licence, visit http://creativecommons.org/licenses/by/4.0/. 
transboundary movements of wastes. Within this traditional legal perspective, States are virtually free to generate and to dispose of wastes as they see fit, so long as such wastes do not cause harm beyond their national jurisdiction (Rayfuse 2016).

To address the challenges involved in the regulation of waste, this paper is concerned with the management of wastes generated on-board vessels (through machinery, cargo, and living spaces) after they are discharged on land to port reception facilities. Ship wastes were chosen because they are incidentally regulated within the regime of marine pollution. At the international level, ship wastes are governed by the International Convention for the Prevention of Pollution from Ships 1973 as Modified by its 1978 Protocol (hereafter MARPOL). The consequence has been the development of a preventive regime that strictly regulates harmful substances (including wastes) while at sea, restricting discharges in the marine environment. Focusing on the prevention of pollution in specific environmental media (e.g., the sea) leaves little room for a life-cycle waste approach in relation to the management of wastes once they are discharged on land. Consequently, there is a risk of transforming ship-source marine pollution into land-based pollution.

Additionally, the prevention of ship-source pollution is heavily reliant on the provision of adequate port reception facilities for the discharge of wastes that otherwise would end up in the sea. The Parties to this treaty, however, have been reluctant to develop the meaning and extent of the obligation related to the provision of port reception facilities (Mitchell 1994; Tan 2006) and the relationship between these facilities and further downstream management operations. Such reluctance could be understood from the traditional legal approach towards "domestic wastes," i.e., once wastes are discharged on land, States manage these wastes at their discretion.

In June 2019, Directive (EU) 2019/883 on Port Reception Facilities for the Delivery of Wastes from Ships repealed Directive No. 2000/59/EC. This Directive gives substantial content to the obligation to ensure the provision of adequate port reception facilities. Directive (EU) 2019/883 offers a valuable opportunity to evaluate the integration of ship waste management within wider EU waste legislation and national waste management plans. Although it is too early to evaluate the impact of this Directive, the paper examines the main features of this new piece of legislation, explains main differences with its predecessor, and explores possible impacts on ship waste management.

\section{Port reception facilities: Interface regulation between international and EU Law}

The relationship between MARPOL and Directive (EU) 2019/883

From its inception, EU legislation on port reception facilities intended to give full effect to its international counterpart, i.e., MARPOL. In this regard, what triggered the adoption of Directive (EU) 2019/883 was eliminating inconsistencies between Directive 2000/59/EC and MARPOL, especially those concerning the definition of waste and the introduction of new waste categories (European Commission 2016a).

The repealed Directive 2000/59/EC on Port Reception Facilities was the result of a growing frustration at the lack of enforcement mechanisms of MARPOL's standards. 
The immediate catalyst, however, was the Erika affair ${ }^{1}$ (Rue and Anderson 2009). Directive 2000/59/EC was welcomed as a way of implementing MARPOL because unlike international law, EU legislation is supported by non-compliance mechanisms against EU Member States. In fact, several States including Finland, Germany, Greece, Italy, and Spain have been brought by the Commission before the Court of Justice of the European Union for not complying in time with the obligations set forth in Directive 2000/59/EC (C-523/06 Commission of the European Communities v Republic of Finland 2007; C-26/08 Commission of the European Communities v Federal Republic of Germany 2008; C-81/07 Commission of the European Communities v Hellenic Republic 2008; C-368/07 Commission of the European Communities v Italian Republic 2008; C-480/07 Commission of the European Communities v Kingdom of Spain 2008).

Furthermore, Directive (EU) 2019/883 and its predecessor establish additional binding obligations that have no parallel in MARPOL, with regard to: a) waste reception and handling plans; b) discharge criteria for ship wastes; c) cost recovery systems, among others. These novel obligations follow, to some extent, soft law instruments adopted under the auspices of the International Maritime Organization (IMO) (International Maritime Organization (IMO) 2016), and as such they could be seen as an effort to complement international obligations that do not compete with their international counterparts.

Since the objective of EU legislation on port reception facilities is to strengthen MARPOL no serious doubts have been raised over the legitimacy and compatibility of the Directive vis-à-vis MARPOL. The EU is not a Party to MARPOL, and in principle the Convention is not binding for the $\mathrm{EU}^{2}$. Nonetheless, MARPOL is not inconsequential within the EU legal order. The implementation of certain MARPOL obligations within Directive (EU) 2019/883 has a direct impact on how EU Member States comply with their international obligations, and it also has an effect on non-EU ships calling at EU ports. Furthermore, in the Intertanko case (C-308/06, Intertanko and Others in ECR I-4057; ECLI:EU:C:2008:312 2008), the Court of Justice of the European Union recognized that in light of the customary international law principle of good faith, MARPOL is relevant for the interpretation of EU secondary legislation falling within the scope of MARPOL's application. The following sections pursue the aforementioned logic with which Directive (EU) 2019/883 and its predecessor are interpreted taking MARPOL into account.

\section{EU competence as a 'port state'}

Article 211(2) of the United Nations Convention on the Law of the Sea (LOSC), prescribe that regulations concerning the prevention of ship-source pollution "shall at least

\footnotetext{
${ }^{1}$ In 1999, the Maltese single-hull tanker, Erika, "broke in two and sank in the Bay of Biscay ... France. The tanker was carrying a cargo of $31,000 \mathrm{t}$ of heavy fuel oil, of which some $19,800 \mathrm{t}$ were spilt at the time of the incident ... Approximately $400 \mathrm{~km}$ of shoreline was affected by the oil, and the incident gave rise to nearly 7000 claims for compensation for the cost of clean-up operations, other pollution preventive measures and economic losses sustained in the fishing and tourism industries." 5. Rue, C.D.L. and C.B. Anderson, Shipping and the Environment: Law and Practice. 2nd Edition ed. 2009: Informa Law. 1247.

2"It is true that all the Member States of the Community are parties to MARPOL 73/78. Nevertheless, in the absence of a full transfer of the powers previously exercised by the Member States to the Community, the latter cannot, simply because all those States are parties to MARPOL 73/78, be bound by the rules set out therein, which it has not itself approved." 12. C-308/06, Intertanko and Others in ECR I-4057; ECLI:EU:C:2008:312. 2008, Court of Justice of the European Union,.
} 
have the same effect as that of generally accepted international rules and standards established through the competent international organization," i.e., MARPOL. From the text of this provision, States are in principle allowed to adopt stricter regulations and enforce them on ships flying their flags. However, regulations of a third State may be applicable to ships voluntarily entering a port of that third State. Ports are located in internal waters, and this maritime zone is closely assimilated to land territory. This means that States exercise territorial sovereignty and, consequently, have full legislative and enforcement jurisdiction.

Considering the territorial nature of internal waters, under customary law prior to the LOSC, port States could legislate ship-source pollution for foreign vessels. For this reason, port States can demand the compliance of ship-source pollution legislation as a condition to allow ships entering into ports as States. In this sense, the LOSC does not modify the legislative jurisdiction of port States. Indeed, Articles 25 (2) and 211 (3) confirm the right of port States to prescribe conditions to access their ports and their offshore terminals. In case of ship-source pollution, such conditions must be communicated to the IMO and port States shall give due publicity of such requirements.

Overall, in the absence of a customary law right of access to ports (de La Fayette 1996; Marten 2014), it is generally accepted that States can impose certain obligations on ships, e.g., the master, the ship operator, voluntarily entering their ports. Controversies over port State jurisdiction pertain not to the existence of such ample jurisdictional powers, but rather to their limits according to public international law. The jurisdictional powers and limits of port State jurisdiction in general and the EU in particular have been discussed elsewhere (Ringbom 2008; Frank 2007; Christodoulou-Varotsi 2009). Suffice it to note here that the EU is increasingly making use of their jurisdictional powers as port States to impose obligations on ship operators. Such obligations not only complement international obligations, but also establish standards that compete with their international counterparts (Ringbom 2008; Christodoulou-Varotsi 2009). Limits of port States' jurisdiction must be analyzed on a case by case basis and in the light of specific treaties and general principles of international law, including good faith, proportionality, reasonableness, and non-discrimination (Marten 2014).

\section{Ship wastes}

Unlike MARPOL, which refers, in general terms, to harmful substances, ${ }^{3}$ Article 2(3) of Directive (EU) 2019/883 explicitly employs the terminology of "waste from ships" concerning operational residues generated in machinery spaces, cargo spaces, and living spaces of a ship 'which falls within the scope of Annexes I, II, VI, V and VI of MARPOL.' The repealed Directive 2000/59/EC had two distinctive waste categories. "Shipgenerated waste" in reference to residues regulated under MARPOL's Annexes I, IV and V, i.e., oil, sewage, and garbage. Other wastes regulated by Directive 2000/59/EC include "cargo residues" defined in Article 2(d) as "remnants of any cargo material onboard in cargo holds or tanks which remain after unloading procedures and cleaning operations are completed and shall include loading/unloading excesses and spillage." These wastes include substances regulated under MARPOL's Annexes I and II.

${ }^{3}$ MARPOL does not employ the terminology of "wastes." It refers in general to harmful substances, which include residues from cargo, machinery, and living spaces of a ship. See Article 1 (1) of MARPOL. 
There is an important caveat in relation to MARPOL Annex V, i.e., garbage. This Annex was comprehensively revised in 2011 ((MEPC), M.E.P.C n.d.) when new categories of garbage were developed, including "cargo residues." Regulation 1 (2) of said Annex defines cargo residues as:

"any remnants of any cargo which are not covered by other Annexes to the present Convention and which remain on the deck or in holds following loading or unloading, including loading and unloading excess or spillage, whether in wet or dry condition or entrained in wash water but does not include cargo dust remaining on the deck after sweeping or dust on the external surfaces of the ship."

According to Article 7(1) of Directive 2000/59/EC, mandatory discharge standards are only applicable to ship-generated wastes, but not to cargo residues. The category of "cargo residues" under Annex V created difficulties for port users calling at an EU port, since it is not entirely clear whether those wastes are subject to mandatory discharge criteria. However, all residues under Annex $\mathrm{V}$ must be considered ship-generated wastes for the purposes of Directive 2000/59/EC (C/2016/1759 Commission notice Guidelines for the interpretation of Directive 2000/59/EC on port reception facilities for ship generated waste and cargo residues 2016). Current Directive (EU) 2019/883 addresses this situation inadequately. Although the Directive includes cargo residues within the definition of 'wastes from ships' the category 'cargo residues' remains in Article 2(5) and these residues are still subject to distinct obligations as further discussed in this article, e.g., cost recovering systems. In practice, difficulties concerning interpretation will persist. From the text of Directive (EU) 2019/883, it appears that cargo residues as defined in MARPOL Annex $\mathrm{V}$ are subject to distinct obligations and exclusions.

Practical reasons triggered the distinction between ship-generated wastes and cargo residues. Cargo residues come from a vast variety of cargoes, e.g., hazardous chemicals. Some residues remain property of the cargo owner. Others require specialized facilities for collection, storage, and treatment (European Maritime Safety Agency (EMSA) 2010). As such, it is common practice for ship operators to contact private waste management operators with little or no involvement of the port authorities. In fact, port authorities in Europe generally consider that cargo residues are somehow outside the scope of their responsibilities, placing accountability on the ship operator and the "individual terminal." (European Maritime Safety Agency (EMSA) 2010; Ramboll 2012) In the Baltic Sea area, the author conducted a survey concerning the collection of cargo residues (MARPOL, Annex II) to sixty one (61) ports that receive noxious liquid cargoes. In $52 \%$ of ports, ${ }^{4}$ external waste management operators were in change of handling the collection of MARPOL - Annex II residues (Argüello 2019).

Article 6 of Directive 2000/59/EC obliges shipmasters to notify in advance the amount of ship-generated wastes and cargo residues to be delivered at port reception facilities or that are kept on-board before entering an EU port. Such information must be available to the relevant authorities. Despite this obligation, the communication

${ }^{4}$ These ports include: Frederiks-havn, Kunda, Tallin, Kemi, Kokkola, Pietarsaari, Turku, Uusikaupunki, Lubmin, Riga, Kolobrzeg, Gävle, Karlshamn, Luleå, and Södertälje. 
between the port authorities and the individual terminals regarding cargo residues is limited (Panteia and PWC 2015). In the Baltic Sea area, for instance, in $45 \%$ of ports, ${ }^{5}$ information concerning volume $\left(\mathrm{m}^{3}\right)$ of cargo residues 'actually delivered' is not available because port authorities are not engaged in the collection of these wastes and do not file or handle these data (Argüello 2019). This had a negative impact on the implementation and enforcement of Directive 2000/59/EC. If the relevant authorities have little or no knowledge of cargo residues, it is not possible for them to assess whether ships are complying with their discharge obligations as provided in Articles 10 and 11 of Directive 2000/59/EC. Moreover, the lack of information also hinders the compliance of obligations set out in the Waste Framework Directive, including the obligation to ensure the traceability of hazardous wastes. Overall, the control and monitoring of the reception and further management of cargo residues on land are weak. Directive (EU) 2019/883 makes a positive step to ensure that waste delivery information is available among enforcement authorities. According to Article 6 (2), "information from the advance waste notification shall be reported electronically" through the Union Maritime Information and Exchange System (SafeSeaNet). Besides, Article 6(3) imposes an obligation to notify and share information "with relevant authorities." This is a welcomed development since information must be shared independently of whether port authorities are involved in the collection and management of such wastes.

The distinction between ship-generated waste and cargo residues has generated complications for port users. Shipmasters find difficulties in assessing the different categories of wastes according to MARPOL and Directive 2000/59/EC. In fact, shipmasters are subject to different notification forms depending on whether they call at an EU port or a port located elsewhere (European Commission 2016a). For this reason, in 2015, the notification form set forth in Directive 2000/59/EC was amended (Commission Directive (EU) 2015/2087 amending Annex II to Directive 2000/59/EC on port reception facilities for ship-generated waste and cargo residues n.d.). The amended form follows closely the IMO Advanced Notification Form for Waste Delivery to Port Reception Facilities (Consolidated Guidance for Port Reception Facility Providers and Users 2014). This amendment aims to avoid administrative burdens for port users as well as reflect the amendments of MARPOL, Annex V. It is expected that ships notify the quantities of wastes "actually delivered at port." The information could potentially be used to develop waste management plans. Annex II of Directive (EU) 2019/883 also contains a revised notification form that follows closely IMO formats.

\section{The relation between ship wastes and wider EU waste legislation}

Considering life-cycle approaches towards waste there is a growing awareness that ship wastes cannot be handled in isolation from other "land wastes". According to Article 2 of Directive (EU) 2019/883, waste from ships shall be considered wastes within the meaning of Article 3(1) of Directive 2008/98/EC on Wastes (hereafter Waste Framework Directive). This provision becomes relevant for the management of wastes once they are discharged to port reception facilities since while on-board vessels, the

\footnotetext{
${ }^{5}$ These ports include: Copenhagen, Fredericia, Frederiks-havn, Randers, Kunda, Rauma, Lubmin, Riga, Ventspils, Gothenburg, Luleå, Malmö, and Norrköping
} 
management of these substances, including their accidental and operational discharges, are in principle governed by MARPOL.

Everything that is not governed by Directive (EU) 2019/883 will be subject to the Waste Framework Directive. Directive (EU) 2019/883 provides for the collection of wastes at port reception facilities, but management activities related to transport, recycling, re-use, recovery, and final disposal operations must follow the Waste Framework Directive and other relevant EU waste legislation. General duties set forth in the Waste Framework Directive must also guide the application of Directive (EU) 2019/883, including the protection of human health and the environment as established in article 13. States are obliged to adopt measures so as to achieve such a general duty. This obligation was subject to judicial scrutiny in the Comitato di Coordinamento per la Difesa della Cava and Others v. Regione Lombardia and others case. The Court of Justice considered that this provision had no direct effect since it does not provide for "specific measures or a particular method of waste disposal. It is therefore neither unconditional nor sufficiently precise and thus is not capable of conferring rights on which individuals may rely as against the State." (Case C-236/92 Comitato di Coordinamento per la Difesa della Cava and Others v Regione Lombardia and others, in ECR 1994 I-00483, ECLI:EU:C:1994:60 1994; Reddish 1994).

\section{Waste hierarchy}

The management of ship wastes must also follow the waste management hierarchy, that is, the priority order that ranks "waste prevention" as the most desirable option followed by preparation for re-use, recycling, other recovery operations and final disposal. In the REFIT ${ }^{6}$ evaluation (European Commission 2016b) of Directive 2000/59/ EC, the European Commission noticed that waste reception and handling plans developed by EU ports do not clearly reflect how the waste management hierarchy in general and waste prevention in particular are included in such plans (European Commission 2016a). Waste reception and handling plans do not implement the waste hierarchy because waste legislation was not drafted taking into account the particularities of shipping. Port authorities could face difficulties in the application of waste obligations in a maritime context. A further obstacle concerns the evaluation on whether a certain national or municipal legislation is applicable to wastes delivered to port reception facilities.

The EU has taken certain subtle actions to prevent and minimize ship-generated waste, without establishing obligations related to on-board operations, equipment, or ship design. Article 8(2)(c) of the repealed Directive 2000/59/EC prescribes that fees for ship-generated wastes "may be reduced if the ship's environmental management, design, equipment and operation are such that the master of the ship can demonstrate that it produces reduced quantities of ship-generated waste." Although Member States have implemented such provision, few EU ports apply it (Panteia and PWC 2015) because in the absence of minimum criteria regarding actual on-board practices and

\footnotetext{
"REFIT is a key component of the Commission's Better Regulation Agenda." It is a mechanism to assess EU legislation "through a system of impact assessments, retrospective evaluations and stakeholder consultations." 28. European Commission. REFIT: Making EU lighter, simpler, and less costly. 2016 [cited 201719 April]; Available from: http://ec.europa.eu/smart-regulation/docs/refit_brochure_en.pdf. last accessed 4 July 2018.
} 
potential waste handling mechanisms to reduce the generation of wastes, the provision remains of limited utility.

Svaetichin and Inkinen (Svaetichin and Inkinen 2017) found that fees' reduction concerning waste management from the cruise industry in the ports of Copenhagen, Helsinki, Stockholm and Tallinn vary from port to port. In the port of Helsinki, for instance, no fee reduction was applicable. In 2017, EMSA commissioned a study regarding on-board waste management treatments, methods, and technologies used to reduce the quantities of shipgenerated waste (CE Delft and CHEW 2017). The gathering of these data could inform ship waste management in several ways. First, for every type of ship-generated waste, guidelines related to best available techniques should be developed to serve as a basis on which to demonstrate waste minimization, and consequently ship operators may benefit from a reduced fee while using port reception facilities.

Second, the EU can also introduce direct obligations relating to on-board practices to secure the prevention of ship-generated waste for vessels bound for EU ports. If these practices follow, for example, IMO recommendations in the field of waste prevention, binding obligations could become a welcome development. Such a legislative approach could also exert pressure for the adoption of binding regulations at the international level. The history of MARPOL shows that States are more inclined to adopt strict regulations to improve on-board management practices and technological equipment of ships, rather than imposing obligations on the actual provision and functioning of port reception facilities (Mitchell 1994; Tan 2006). This legislative approach is partially adopted in Directive (EU) 2019/883. Article 8(5)(b) incorporates a fee reduction system in cases where "ship's design, equipment and operation demonstrate that the ship produces reduced quantities of waste, and manages its waste in a sustainable and environmentally sound manner." While the Directive does not impose direct obligations for vessels bound for EU ports, the Commission has to define the criteria, by 28 June 2020, in relation to on-board practices. If ships meet the criteria, the fee will be reduced accordingly. So, the Directive is creating financial incentives to nudge a behavioral change on ship operators.

\section{Waste reception and handling plans}

According to article 5 of Directive (EU) 2019/883, ports either individually or in a regional setting must develop waste reception and handling plans. The integration of port reception facilities within the broader context of waste management requires that port waste reception and handling plans are adopted and monitored considering national waste management plans set out in Article 28 of the Waste Framework Directive (Panteia and PWC 2015). Although each EU Member State has national waste management policies, the Waste Framework Directive includes several indications of the content of such plans. National waste management plans should be instrumental in achieving a coherent EU waste policy (van Calster 2015). However, some commentators believe that EU waste policy is still inconsistent and subject to "political divergence within the European Union." (Krämer 2015)

\footnotetext{
${ }^{7}$ MARPOL does not contain any explicit obligation to minimize waste. However, the IMO considers that waste management strategies should follow the waste hierarchy. Indeed, the IMO recommends port users to minimize ship wastes. It has also suggested the adoption of ISO 21070: management and handling of shipboard garbage.
} 


\section{Waste separation}

Separate collections of wastes may be necessary to ensure those wastes undergo recovery operations according to the Waste Framework Directive 2008/98/EC. ${ }^{8}$ However, according to the Ex-Post evaluation of Directive 2000/59/EC "only about 25\% of the North Sea ports have waste separation procedures in place" (Panteia and PWC 2015) in relation to garbage management (MARPOL-Annex V). Port users and providers of port reception facilities encounter difficulties in waste separation and collection, since waste legislation among EU Member States varies considerably (Panteia and PWC 2015). These differences are likely to persist for two reasons. First, standards for separate collection of waste differ between jurisdictions since the Waste Framework Directive 2008/98/EC leaves Member States with greater discretion for setting up such separate collections. Regarding recovery and recycling, Articles 10 and 11 provide, respectively, that wastes must be collected separately if "technically, environmentally and economically practicable." The Directive also includes specific obligations for the separation of waste oils ${ }^{9}$ and paper, metal, plastic, and glass. Second, the legal basis of the Waste Framework Directive 2008/98/ EC is Article 192 TFEU. Consequently, and in accordance with Article 193 TFEU, there is no obligation of full harmonization, and States are entitled to enact more stringent measures. The limit, however, is that those "measures must be compatible with the Treaties."

Port users and the providers of port reception facilities face further difficulties since waste classification, set out in MARPOL and Directive 2000/59/EC, is not always equivalent to the categories of waste legislation on land (Panteia and PWC 2015). The classification of wastes varies from one jurisdiction to another, and as such, it is necessary that port waste reception and handling plans include guidelines for providers of port reception facilities to identify the equivalent categories according to waste legislation on land. Annex I of Directive 2000/59/EC requires that waste reception and handling plans incorporate a "summary of relevant legislation." As a result, many ports such as Barcelona (Barcelona, P.d 2014-2016), Felixstowe (Port of Felixstowe 2016), Helsinki (Port of Helsinki 2019), and Rotterdam (Rotterdam, P.o 2018), include lists of local, national, and European legislation without specific guidance on their applicability. Such a summary is not entirely adequate without describing how the relevant legislation relates to ship-generated waste and cargo residues. These problems may persist in the future because Directive (EU) 2019/883 still prescribes that waste reception handling and plans may include "a summary of relevant national law". No reference is made about the potential applicability of such national legislation to ship wastes.

The management of ship-generated waste and cargo residues does not require dedicated treatment installations. Although some ports may have some pretreatment or treatment operations (Ramboll 2012), external private operators are usually in charge of both collection and treatment of ship-generated wastes and cargo residues (Ramboll 2012). For instance, in several Baltic ports including Frederiks-havn, Kunda, Tallin, Kemi, Kokkola, Pietarsaari, Turku, Uusikaupunki,

\footnotetext{
${ }^{8}$ See Articles 10, 11 and 21(1)(a) of the Waste Framework Directive 2008/98/EC.

${ }^{9}$ See Article 21(1)(a) of the Waste Framework Directive 2008/98/EC.
} 
Lubmin, Riga, Kolobrzeg, Gävle, Karlshamn, Luleå, and Södertälje external operators are in charge of collecting cargo residues, from MARPOL Annex II (Argüello 2019). Article 4(2)(d) of Directive (EU) 2019/883 provides that "Member States shall ensure separate collection to facilitate reuse and recycling of waste from ships in ports as required under Union waste law". As discussed in this section, the collection, storage, transport, and treatment of ship waste must follow the waste management hierarchy. However, waste reception and handling plans in several ports of the EU "focus primarily on the disposal of waste, even for waste types that could easily be recycled." (Panteia and PWC 2015)

Favoring disposal stems from a lack of segregation of waste on-board vessels or at port reception facilities (e.g., garbage is not separately collected) (Panteia and PWC 2015), as well as the wide discretion that Member States exercise in choosing waste treatment options. Vaneeckhaute and Fazli reviewed the management of ship generated food waste and sewage in the ports of Helsinki, Stockholm, Tallin, and Copenhagen Malmö to identify best practices (Vaneeckhaute and Fazli 2020). A problem that persists is "the current combined storage of black water, grey water and/or food waste in the same tank which affects the potential and efficiency of later treatment." (Vaneeckhaute and Fazli 2020) So, improved waste separation on-board is paramount to improve waste management on land.

For specific waste streams, Article 4(2) of the Waste Framework Directive 2008/98/ EC gives Member States the capacity to depart from the priority order established in the waste management hierarchy if it is justified from a life-cycle approach. The strict application of the hierarchy may involve higher risks for the environment and human health. In this case, it is reasonable to depart from the priority order (European Commission 2012). In practice, however, Member States choose - more or less freely whether wastes are going to be composted, recycled, incinerated, or landfilled. For this reason, some scholars consider that the waste management hierarchy resembles more a recommendation than a binding obligation (Krämer 2015) (Moules 2011). The European Commission deems such a hierarchy as binding, albeit subject to a certain degree of flexibility. From the wording of Article 4(1) of the Waste Framework Directive 2008/ 98/EC, it appears that following the waste management hierarchy is a legal obligation since States "shall apply" this priority order in their waste policy and legislation. Thus, Article 4(1) imposes a legal constraint (Fisher et al. 2013), but the exceptions to deviate from the hierarchy provided in Article 4(2) are so wide that in practice the enforcement of such an obligation is extremely difficult.

\section{Waste oils, hazardous wastes and recovery targets}

Other obligations of the Waste Framework Directive 2008/98/EC that are particularly relevant for ship wastes pertain to: a) waste oils, e.g., ship-generated wastes from MARPOL Annex I - oil; b) separate collection and recovery targets for paper, metal, plastic, and glass, e.g., ship-generated waste from MARPOL Annex V - garbage; and c) hazardous wastes, e.g., cargo residues from MARPOL Annex II - harmful substances carried in bulk. Subject to certain exemptions, waste oils must be collected separately, and these wastes shall not be mixed with other wastes or with waste oils of different characteristics. Furthermore, Member States could enact laws regarding the regeneration of 
waste oils. ${ }^{10}$ Member States are obliged to set up separate collections for paper, metal, plastic, and glass, and by 2020 the preparation for re-use or recycling of these waste materials must increase to at least $50 \%$ by weight. ${ }^{11}$ These obligations are especially difficult to implement in respect of the management of ship-generated wastes from MARPOL Annex V, i.e., garbage, because many port reception facilities are not usually "supportive of the on-board separation efforts of solid waste." (Panteia and PWC 2015) The lack of waste segregation on-board and at port reception facilities limits the possibility of waste recovery. A study concerning the handling of food waste on passenger ships operating in the Baltic Sea area revealed that food waste is mixed with wastewater while on-board. Such mixtures deteriorate sewer systems on land (Wilewska-Bien et al. 2018). Possible solutions include food waste reduction practices and the installation of separate food waste collection systems to allow further management at land to produce, for instance, biogas (Wilewska-Bien et al. 2018).

In terms of hazardous wastes, Member States are obliged to ensure their traceability, in accordance to Article 17 of the Waste Framework Directive 2008/98/EC i.e., from production to final treatment. To this end, producers and operators, including dealers and brokers, who collect and transport hazardous wastes must keep records detailing the quantity, nature, mode(s) of transport, destination, and treatment method of the waste. In port reception facilities, the traceability of hazardous wastes, e.g., cargo residues, is problematic since port authorities are generally not involved in any stage of hazardous waste management, e.g., collection and transport. In a survey conducted among ports receiving noxious liquid cargoes (MARPOL, Annex II) in the Baltic Sea area, $45 \%$ of the respondents declared that port authorities do not manage such information because "ship agents or terminals are responsible for the collection of cargo residues" (Argüello 2019) while another 27\% do not have the information because no cargo residues are discharged in those ports (Argüello 2019). Even though EU legislation obliges shipmasters to provide information on ship wastes to the designated authority, EU ports generally lack adequate systems to collect, exchange, and monitor information regarding ship wastes in general and cargo residues in particular (European Commission 2016a).

Overall, the inclusion of waste from ships as wastes within the meaning of wastes set out in the Waste Framework Directive 2008/98/EC is not enough to provide an adequate basis to achieve the environmentally sound management (ESM) of ship wastes. It is necessary to reflect how these particular obligations could indeed be applicable to ships wastes. This section has discussed some of the challenges in relation to the alignment of EU legislation on port reception facilities with wider EU waste legislation.

\section{Port reception facilities: obligations and current challenges}

This section provides an analysis of specific obligations related to the provision and operation of European port reception facilities. In addition, this section examines the

\footnotetext{
${ }^{10}$ See Article 21 of the Waste Framework Directive 2008/98/EC. Regeneration of waste oils means, according to Article 3(18) of this Directive, "any recycling operation whereby base oils can be produced by refining waste oils, in particular by removing the contaminants, the oxidation products and the additives contained in such oils."

${ }^{11}$ See Article 11 (1) and (2)(a) of the Waste Framework Directive 2008/98/EC.
} 
difficulties faced by States in the implementation of their obligations and the challenges associated with the ESM of wastes on land.

\section{Waste reception and handling plans}

According to Article 5 of the repealed Directive 2000/59/EC, Member States must develop - whether individually or in a regional context - waste reception and handling plans for ship-generated waste and cargo residues. Article 5 of Directive (EU) 2019/883 has a similar, but more detailed obligation. A welcome development is that the structure of costs must be "clearly communicated to the ship operators ... and ... easily accessible." The development of such plans on a regional basis does not imply, however, that States enjoy the right to provide port reception facilities on a regional basis as well. On the contrary, port reception facilities must be available at every single port considering, for instance, the types of ships that regularly call at a port. This is consistent with MARPOL that requires the availability of adequate port reception facilities at port level. Zuin et al. (Zuin et al. 2009), Svaetichin and Ikinen (Svaetichin and Inkinen 2017) criticize the obligation to provide port reception facilities at port level since waste management on land could be improved if closely-located ports specialize in particular wastes categories.

Annex I of Directive 2000/59/EC details the content of waste reception and handling plans. This Annex includes mandatory and optional requirements. It is obligatory to include: a) an evaluation of the facilities required to satisfy the needs of ships usually calling at a particular port; b) a description of the type and quantities of ship-generated wastes and cargo residues received on land; c) a description of the technical capacity of facilities including the procedures for reception and collection of ship wastes; d) a description of the cost recovery system; e) mechanisms to report alleged inadequacies of port reception facilities, among others. Similar requirements are also established in Annex I, of Directive (EU) 2019/883.

From a practical point of view, the assessment of the type of facilities needed should ideally be based on available data regarding the size and location of the port, volume of traffic, type of vessel calling at the port, and the amount of wastes actually received $(\mathrm{C} /$ 2016/1759 Commission notice - Guidelines for the interpretation of Directive 2000/ 59/EC on port reception facilities for ship generated waste and cargo residues 2016). However, according to the European Commission, the vast majority of plans do not describe the type and quantities of ship-generated waste and cargo residues that are received at port reception facilities (C/2016/1759 Commission notice - Guidelines for the interpretation of Directive 2000/59/EC on port reception facilities for ship generated waste and cargo residues 2016). This is the result of poor collection data mechanisms at port level, and where this information is available, port authorities do not make use of it (Panteia and PWC 2015).

According to Article 6 and Annex II of Directive 2000/59/EC, shipmasters, bound to an EU port, are obliged to notify the type and amount of ship-generated waste and cargo residues "to be delivered and/or remaining on-board." However, for many port authorities, collecting this information may be burdensome, especially where electronic means are not available (European Commission, Roadmap 2015). To simplify data collection and to reduce administrative burdens for port authorities and shipmasters, from 
June 2015, EU Member States must "accept" that certain reporting obligations are transmitted electronically through a "single window" in accordance with Article 5 of Directive 2010/65/EU on reporting formalities for ships arriving in and/or departing from ports of the Member States. Article 6(2) of Directive (EU) 2019/883 imposes the obligation to report this information electronically.

If these electronic means are indeed implemented, they could simplify the systematization and analysis of such data. It could also enhance the harmonization of data to assess, for example, the quantities and type of ship-generated waste not only at port level, but also at regional or EU level. In the REFIT Revision of EU Directive 2000/ 59/EC on port reception facilities, the European Commission found that port authorities collect the required information "on the basis of their own data needs, using their own units of measurement." (European Commission, Roadmap 2015) Collecting and making use of the information on ship wastes that are actually received at port reception facilities is vital not only in developing waste reception and handling plans, but also in monitoring and enforcing.

\section{Mandatory discharge criteria for ship-generated waste}

Article 7 of Directive 2000/59/EC provides that ships calling at an EU port must deliver all ship-generated waste to port reception facilities before leaving said port. From the wording of this provision it is uncertain whether operational discharges at sea (which MARPOL allows) are still legal for ships calling at an EU port. According to the Commission, Directive 2000/59/EC aims at supporting the full implementation of MARPOL "instead of introducing new discharge rules for ships." (Commission of the European Communities 1998) Thus, it is reasonable to conclude that this provision establishes a binding obligation for ships in ports, which does not affect the operational discharge standards established in MARPOL. However, the position of the Commission seems to have changed. In the interpretative guidelines of Directive 2000/59/EC, the Commission takes a bold yet cautious step towards a zero-discharge standard, by stating:

the overall delivery requirement should be interpreted in the light of the Directive's objectives of reducing ship-generated waste into the sea and enhancing the protection of the marine environment. Therefore, the Commission takes the view that what is allowed to be discharged under MARPOL cannot be automatically excluded from the delivery requirement in the Directive (C/2016/1759 Commission notice - Guidelines for the interpretation of Directive 2000/59/EC on port reception facilities for ship generated waste and cargo residues 2016).

If this policy is actually pursued, such action will disrupt the jurisdictional framework prescribed in the LOSC, since it would be an attempt to extend legislative jurisdiction beyond internal and territorial waters because many operational discharges allowed by MARPOL occur beyond $12 \mathrm{~nm}$ from the nearest land.

If adequate port reception facilities are available and enforcement mechanisms are in place, e.g., port State control, then establishing compulsory discharge criteria is an effective mechanism through which to avoid illegal discharges at sea. There is, however, an exception regarding the general obligation to discharge ship-generated wastes at port reception facilities. According to Article 7(2) of Directive 2000/59/EC, if there is "sufficient dedicated storage capacity," the ship may keep on-board the ship-generated 
waste and proceed to the next port of call regardless of whether this port is within the EU. Port authorities face many difficulties in assessing whether ships have sufficient dedicated storage capacity. Empirical evidence shows significant differences in the application of this provision between EU Member States, whereby interpretation is left to the discretion of port authorities. "France, for instance, requires that ships have at least $30 \%$ of the waste storage capacity available before leaving port, while Sweden requires at least 70\% of waste storage capacity available." (Panteia and PWC 2015) Additionally, a survey of ports, port users, member states, port reception facilities' operators, and other organizations revealed that $44 \%$ of port users were obliged to discharge wastes although having sufficient storage capacity (Panteia and PWC 2015). Considering that the general provision demands that all ship-generated waste is delivered at port reception facilities, the exception cannot become the rule, and the application of such an exception must be strict. Nonetheless, port users fear that using port reception facilities in every port instead of keeping wastes on-board could increase their operational costs (Panteia and PWC 2015). The needs of port users must also be taken into account when applying the mandatory discharge criteria because it can translate into an incentive to discharge ship-wastes at sea, or to deliver them to a cheaper facility - whether "adequate" or otherwise.

Dedicated storage capacity is not, however, the only relevant aspect when evaluating whether a ship is exempt from the application of the mandatory discharge criteria. Article 7(2) of Directive 2000/59/EC prescribes:

[i] $\mathrm{f}$ there are good reasons to believe that adequate facilities are not available at the intended port of delivery, or if this port is unknown, and that there is therefore a risk that the waste will be discharged at sea, the Member State shall take all necessary measures to prevent marine pollution, if necessary by requiring the ship to deliver its waste before departure from the port.

This article imposes a precondition to allow a vessel to procced to its next port of call and that inevitably requires a case-by-case analysis based on general information available to port authorities. If the next port of call is outside the EU, this article raises some theoretical questions regarding extra-territorial jurisdiction since the provision calls for the assessment of the "adequacy" of port reception facilities located in another jurisdiction. However, the provision is of such a general nature that it can hardly be construed as an interference of the sovereignty or territorial integrity of other States. The situation will be different if Member States intend to monitor, supervise, or exercise control activities on port reception facilities outside their jurisdictions. From a practical point of view, it is unlikely that this article will raise many questions since several jurisdictions outside the EU avoid imposing mandatory discharge provision because the management of wastes on land is an additional burden. So, the provision could be seen as a welcome development that could potentially avoid not only marine pollution, but also the transformation of one form of pollution into another, by avoiding the discharge of wastes in jurisdictions that still face challenges over the provision of port reception facilities.

Article 9(1) of Directive 2000/59/EC contains another exemption from the application of the mandatory discharge criteria for ships "engaged in scheduled traffic with frequent and regular port calls and there is sufficient evidence of an arrangement to ensure the delivery of ship-generated waste ... in a port along the ship's route." This 
exception could be granted in cases where the cost recovery system of port reception facilities is based on contracts and the payments for delivering wastes are made on a monthly or annual basis, for instance. However, several port authorities lack access to relevant information that could provide evidence of such arrangements (Panteia and PWC 2015). Such relevant information includes, but is not limited to, contracts and receipts showing that such contractual arrangements are still valid (C/2016/1759 Commission notice - Guidelines for the interpretation of Directive 2000/59/EC on port reception facilities for ship generated waste and cargo residues 2016). For instance, the Swedish Transport Agency grants the exemption for mandatory delivery if the following conditions are met:

[f] requent and regular calls means that they occur at the same Swedish port within a fortnight. Such ships shall also have made a special agreement with a waste contractor or port on waste delivery. The ships shall also have enough capacity on-board to store the waste generated until it can be delivered at a port reception facility. If any of the circumstances granting exemption are changed, the application must be renewed (Swedish Transport Agency 2019).

Fort the exemption to be granted, ship operators must also specify the type of waste, identify the company or port that will collect the wastes, and provide evidence of the scheduled traffic (Swedish Transport Agency 2019).

Article 9(1) of Directive 2000/59/EC aims to prevent any undue burdens for port users and port authorities in cases where a vessel has recurring journeys between identified ports. The provision is silent on whether the exemption applies to a specific journey or is valid for a limited period of time while the vessel is engaged on the same scheduled traffic and while the arrangement for delivery of ship-generated wastes remains valid. Considering the rationale behind the establishment of such provision, it is reasonable to conclude that a port authority will provide an exemption for a determined period of time. In Sweden, it appears that the exemption is granted as long as the vessel follows the same route and the ship is not replaced (Swedish Transport Agency 2019).

Article 9 of Directive (EU) 2019/883 preserves this exemption but establishes clear criteria to identify ships that will benefit from it. Particularly, there should be a contract in place, all ports on the ship's route must be notified, and the port where the delivery is going to take place must accept the arrangement. The port could be located in the EU or elsewhere. This Article opens the possibility for ships to leave the EU without discharging wastes in cases where vessels are engaged in scheduled traffic with frequent and regular port calls. This is a negative development due to the limited legal possibilities to assess whether port reception facilities outside the EU are adequate.

\section{Discharge criteria for cargo residues}

Article 10 of Directive 2000/59/EC does not impose mandatory discharge criteria for cargo residues, which must be discharged in accordance with MARPOL standards. MARPOL does not specify where or when "cargo residues" must be discharged. This means that ship operators can freely choose the port reception facility where they will discharge the residues. There are two exceptions to this general rule: 
- Ships carrying substances, "which through their physical properties inhibit effective product/water separation, and monitoring, including asphalt and high-density oils," must discharge their residues at the unloading port. ${ }^{12}$

- Ships carrying MARPOL, Annex II, substances of category X need to pre-wash their tanks and discharge the residues at the unloading port. If substances of categories $Y$ or $\mathrm{Z}$ are not unloaded following the procedures established in Appendix IV of MARPOL, Annex II, tanks must also be pre-washed. ${ }^{13}$ However, if ships load the same substance, the relevant authority could make an exception for a pre-wash.

In general, dedicated terminals receive cargo and cargo residues with little or no involvement from port authorities (Ramboll 2012). Thus, the relevant authorities are not in charge of making exemptions from required pre-washes, for instance, leaving this responsibility to the terminal. In the absence of information exchange between port authorities and terminals, it is difficult to assess how port authorities verify that ships are complying with the discharge criteria established in MARPOL, Annex II, and the procedures concerning the cleaning of cargo tanks, the discharge of residues, ballasting, and deballasting.

The discharge criteria established in Directive (EU) 2019/883 is a step back from its predecessor. Article 7 (1) prescribes that a ship "calling at a Union port shall, before leaving the port, deliver all its waste carried on-board to a port reception facility in accordance with the relevant discharge norms laid down in the MARPOL Convention." MARPOL does not oblige ships to deliver wastes on specific port reception facilities, with the exceptions previously explained. As long as vessels have sufficient dedicated storage capacity in accordance with Article 7(4)(a)(b), ship operators are free to choose the port reception facility. European port authorities could nonetheless oblige ship operators to discharge wastes before departure in the following situations: a) if adequate port reception facilities are not available in the next port of call, and b) the next port of call in unknown. Considering that collecting and managing wastes is an additional burden to port States, it is uncertain up to what extent authorities will implement and enforce such an obligation. Mandatory discharge criteria under Directive (EU) 2019/883 is only exceptional. This could certainly lead to increasing illegal discharges at sea and/ or discharges to inadequate port reception facilities.

\section{Cost recovery system}

Directive 2000/59/EC adopted the polluter pays principle that serves as the basis for establishing cost recovery systems. Day-to-day operations of port reception facilities generate environmental externalities derived from the reception and management of shipgenerated wastes. These externalities must be internalized by port users, i.e., ships, rather than by other members of society. Concerning ship-generated wastes, Article 8(2) of Directive 2000/59/EC provides for the application of a combined cost recovery system, which incorporates both an indirect cost recovery mechanism in addition to an extra direct fee. Directive (EU) 2019/883 keeps a combined recovery system for waste from ships, other than cargo residues. Thus, everything that is not covered by the

\footnotetext{
${ }^{12}$ See regulation 2.4 of Annex I, and numerals 7 and 62 of the Unified Interpretations of Annex I of MARPOL.

${ }^{13}$ See regulations 13.6 and 13.7. of MARPOL, Annex II.
} 
indirect fee will be subject to direct fees based on the type of wastes and the quantities delivered to port reception facilities. Article 8(4) of the current Directive allows differentiated fees based on: "(a) the category, type and size of the ship; (b) the provision of services to ships outside normal operating hours in the port; or (c) the hazardous nature of the waste."

Concerning the combined recovery system, Article 8(2)(a) of Directive 2000/59/ EC provides that all ships calling at an EU port must "contribute significantly to the costs" for the reception and treatment of ship-generated wastes. The costs can be included in port dues or as separate waste charges. The establishment of such a fee is based on several parameters, e.g., ship type, size, on-board equipment, crew and/or passenger number, the type of ship-generated waste and the required treatment. According to the Commission, "significantly" means that the fee should cover at least $30 \%$ of the costs. Nonetheless, Member States have considerable discretion in deciding what should be deemed a significant contribution. This discretion is coming to an end with the entrance into force of Directive (EU) 2019/883 since Article 8(2)(b) explicitly establishes that the indirect fee must cover indirect administrative costs and "a significant part of the direct operational costs, which shall represent at least 30\% of the total direct costs." The payments are made regardless of whether a ship uses a port reception facility. In other words, the provision establishes an indirect cost recovery system that aims to discourage the discharge of wastes at sea by allocating costs "over the community of users collectively." (Brinkmann 2016) The implementation of the provision established in the repealed Directive 2000/59/EC varies considerably among EU Member States and, in some cases, significant differences are also found at port level (Ramboll 2012). For instance, Bulgaria, Cyprus, Denmark, Estonia, Finland, Greece, Latvia, Lithuania, Poland, Spain, Sweden, and the Netherlands have implemented an indirect fee, but some will only accept determined waste volumes (Argüello 2019). German ports adopted a reversed model of indirect recovery system where "ship masters pay a direct fee, which can be reclaimed, after wastes are delivered." (Argüello 2019) In Belgium ports, a deposit system is the place where ship operators pay an indirect fee that "could be partially refunded." (Argüello 2019)

A direct fee system governs the reception and management of cargo residues. In relation to cargo residues subject to MARPOL, Annex II, the establishment of an indirect fee system may be difficult, given: a) the variety of cargo residues and the specialization required for their management; and b) the lack of knowledge by port authorities regarding the type and quantities of cargo residues that ships actually discharge at port reception facilities.

Empirical evidence demonstrates that port reception facilities receive fewer quantities of wastes if $100 \%$ direct fee systems are in place (European Commission 2016a; Panteia and PWC 2015). Therefore, indirect or combined cost recovery systems should be preferred to avoid creating incentives for ships to discharge wastes at sea. In cases where direct recovery systems are in place, mandatory discharge criteria must also be implemented and coupled with effective monitoring and enforcement mechanisms not only to prevent illegal discharges, but also to avoid competitive distortions between ports. In the case of cargo residues, where direct fee systems are implemented, establishing framework contracts with waste 
operators could enhance monitoring activities regarding this type of waste, as well as improving communication channels between port authorities and waste operators. Cargo residues are still excluded from the indirect fee system under Directive (EU) 2019/883. It appears that States enjoy a considerable latitude of discretion to establish the appropriate recovery system. Indirect fees do not cover waste from exhaust gas cleaning systems in accordance with Article 8(2)(f). Port users must pay through a direct fee system, i.e., based on the type and quantity of waste delivered.

Over the years, MARPOL Annex V, i.e., garbage, has continually restricted the discharge of wastes at sea. In addition, since the adoption of Directive 2000/59/EC, the delivery of garbage has increased in EU ports (Panteia and PWC 2015). Article (8)(2)(c) of Directive (EU) 2019/883 establishes a combined cost recovery system for garbage (other than cargo residues), i.e., an indirect fee coupled with a direct fee based on the volume of wastes when it "exceeds the maximum dedicated storage capacity."

\section{Concluding remarks}

Due to the challenges faced by European Ports, a revision of Directive 2000/59/EC started in January 2018 to repeal this piece of legislation. Directive (EU) 2019/883 on Port Reception Facilities for the Delivery of Waste from Ships entered into force in June 2019. It is too early to assess the impacts of this Directive, but this section summarizes the main changes brought by this Directive (European Commission COM (2018) 33 final n.d.).

The revision of Directive 2000/59/EC was indeed necessary to enhance the integration of ship-generated wastes and cargo residues into wider EU waste legislation. Several aspects should be considered when addressing the management of ship wastes on land and the challenges that port users and port authorities face. First, there is a need for harmonization of terminology between MARPOL and EU legislation. Article 2(3) of Directive (EU) 2019/883 takes a positive step in this direction by including a general definition of 'waste from ships' that includes cargo residues as well as residues subject to MARPOL, Annex VI. This potential amendment is also the result of regulatory developments at the international level. Regulation 17 of MARPOL, Annex VI, requires that State Parties provide reception facilities for "exhaust gas cleaning residues and exhaust gas cleaning systems." ${ }^{14}$ Although Directive (EU) 2019/883 gives a general definition of waste from ships, the category 'cargo residues' is still maintained in Article 2 (5) due to the practical difficulties related to the management of such wastes as presented in this paper.

Second, mandatory discharge criteria for all categories of ship wastes should have been included in the current Directive (EU) 2019/883. Compulsory discharge criteria include the correlated obligation of States to manage such waste on land in an environmentally sound manner without transforming one source of pollution into another. This could prove particularly challenging for cargo residues due to the diversity of these residues as well as for the practices around ports that leave

\footnotetext{
${ }^{14}$ In ports where ships undergo repairs or where ships are dismantled, facilities should be available for the reception of "ozone-depleting substances and equipment containing such substances when removing from the ship." Since repairs and ship breaking are not within the day-to-day operations of ships, this requirement will probably be left outside the scope of the Directive.
} 
the management of such residues to individual terminals. The discharge criteria set up in article 7 of Directive (EU) 2019/883 is far from satisfactory. The general rule indicates that before leaving the port, the master of a ship delivers the wastes in accordance to MARPOL. As discussed in this paper, MARPOL does not impose compulsory standards that specify the location where ship wastes must be discharged, e.g., the unloading port. Therefore, ships with enough holding capacity can freely choose, subject to some exceptions, the port reception facility for the discharge of wastes. This obligation is certainly weaker than the one provided in the repealed Directive 2000/59/EC. Without strict criteria that allows to assess whether the next port of call has adequate port reception facilities, ship wastes will follow the path of least resistance.

Third, in order to improve the traceability of these wastes on land it is necessary to include obligations regarding cooperation and exchange of information between dedicated terminals, waste operators, and port authorities. It is positive that Article 13 of Directive EU 2019/883 includes reporting and exchange of information based on the Union Maritime Information and Exchange System (SafeSeaNet). This information will be transmitted to the IMO electronic database GISIS. This IMO database aims at increasing the reporting rate among State Parties and enabling "coordination with relevant intergovernmental organizations ... research on trends [and] statistical analysis." (Assembly of the International Maritime Organization (IMO) 2010) In the pursuit of transparency, States are encouraged to use GISIS as an effective way to comply with their reporting obligations under MARPOL (Assembly of the International Maritime Organization (IMO) 2013).

Finally, transparency and waste management fees should also be addressed, especially in relation to cargo residues. Article 8 (6) of Directive (EU) 2019/883 specifies that waste from ships other than cargo residues shall be covered by an indirect fee and if necessary, by a direct fee. The positive development of the proposal is the establishment of the basis for the calculation of waste fees. However, cargo residues continue to be excluded from the fee system. This implies that direct contractual arrangements between the ship operator and the terminal will continue to take place. Such scheme certainly hinders the monitoring of obligations.

Directive (EU) 2019/883 fails to reflect how: a) the waste management hierarchy is going to be incorporated into waste reception and handling plans; b) the support of waste-minimization practices on-board ships; and c) the provision of waste segregation and separate collection obligations. The inclusion of waste from ships within the meaning of the Waste Framework Directive 2008/98/EC has proven to be insufficient as previously discussed in this paper. In general, the integration of ship wastes with wider EU waste legislation will continue to be the major challenge. This uncertainty is a common problem of what Ringbom calls "horizontal environmental requirements," (Ringbom 2008) i.e., "EU legislation of activities that could occur on-board ships or that regulates substances that could be transported or generated by ships." (Ringbom 2008) In the absence of an express provision regarding the relation of a piece of environmental legislation to ships, their applicability remains limited because the rationale behind the adoption of these "horizontal measures" may not always consider the particular features of maritime transport (Ringbom 2008). The revision of Directive 2000/59/EC on Port Reception 
Facilities could have been an opportunity to clarify how and to what extent the obligations of the Waste Framework Directive 2008/98/EC are applicable to these wastes in detail. The Current reference at the EU level to horizontal measures is far from satisfactory since such measures are unrelated to daily shipping operations. The result is the inapplicability of such standards to ships.

\section{Abbreviations \\ ESM: Environmentally sound management; EU : European Union; IMO: International Maritime Organization; LOSC: United Nations Convention on the Law of the Sea, 1982; MARPOL: International Convention for the Prevention of Pollution from Ships 1973 as Modified by its 1978 Protocol; POPs: Persistent organic pollutants}

\section{Acknowledgements}

Not applicable.

\section{Declaration}

A previous version of this article is partially found in Argüello, G., Marine Pollution, Shipping Waste and International Law. Routledge Research in International Environmental Law. 2019, Great Britain: Routledge. This article presents an updated version of current regulatory developments.

\section{Author's contributions}

Not applicable. I am the sole author of this paper. The author(s) read and approved the final manuscript.

\section{Author information}

GA holds a Doctoral degree in Maritime and Transport Law from the University of Gothenburg and a Master in Maritime Law from Lund University (Sweden). Her research interests focus on environmental global challenges in relation to the marine environment and the governance of the oceans. Currently, GA is a Postdoctoral Research Fellow in Law with focus on Large Scale Collective Action at the Centre for Collective Action Research (CeCAR).

\section{Funding}

Open access funding provided by University of Gothenburg

\section{Availability of data and materials}

Not applicable since this paper is a legal research.

\section{Competing interests}

The author declares that she has no competing interest.

Received: 7 August 2019 Accepted: 4 June 2020

Published online: 30 June 2020

\section{References}

(MEPC) (2011), Resolution MEPC.201(62) Revised MARPOL Annex V

Argüello G (2019) Marine Pollution, Shipping Waste and International Law. Routledge research in international environmental Law. Routledge, Great Britain

Assembly of the International Maritime Organization (IMO), Resolution A.1029(26) Global Integrated Shipping Information System (GISIS), in A 26/Res.1029. 2010

Assembly of the International Maritime Organization (IMO), Resolution A.1074(28) notification and circulation through the global integrated shipping information system. 2013

Barcelona, P.d., Plan de Recepción de Desechos de Buques y de Residuos de Carga. 2014-2016

Brinkmann T (2016) Commentary on Directive 2000/59/EC of 27 November 2000 on port reception facilities for shipgenerated waste and cargo residues. In: Jessen $\mathrm{H}$, Werner MJ (eds) Brussels commentary on EU maritime transport law. Nomos, Germany, pp 635-645

C/2016/1759 Commission notice - Guidelines for the interpretation of Directive 2000/59/EC on port reception facilities for ship generated waste and cargo residues (2016) OJ C 115, p 5.16

C-26/08 Commission of the European Communities v Federal Republic of Germany (2008) OJ C 92, pp 13-13

C-308/06, Intertanko and Others in ECR I-4057; ECLI:EU:C:2008:312. 2008, Court of Justice of the European Union,

C-368/07 Commission of the European Communities v Italian Republic, in OJ C 301, p. 10-10; ECLl:EU:C:2008:523; ECR 2008 I00130. 2008, Court (Seventh Chamber)

C-480/07 Commission of the European Communities v Kingdom of Spain, in OJ C 44, p. 18-19; ECLl:EU:C:2008:715; ECR 2008 I-00184. 2008, Court (Second Chamber)

C-523/06 Commission of the European Communities v Republic of Finland, in ECR I-00135, ECLI:EU:C:2007:584. 2007, Court (Sixth Chamber)

C-81/07 Commission of the European Communities v Hellenic Republic, in OJ C 116, p. 8-8; ECLl:EU:C:2008:172; ECR 2008 I00048. 2008, Court (Third Chamber)

Case C-236/92 Comitato di Coordinamento per la Difesa della Cava and Others v Regione Lombardia and others, in ECR 1994 I-00483, ECLI:EU:C:1994:60. 1994

CE Delft and CHEW (2017) The Management of Ship-Generated Waste On-board Ships. EMSA/OP/02/2016. European Maritime Safety Agency (EMSA), Delft, p. 90 
Christodoulou-Varotsi I (2009) Maritime safety Law and policies of the European Union and the United States of America: antagonism or synergy? Springer, Germany

Commission Directive (EU) 2015/2087 amending Annex II to Directive 2000/59/EC on port reception facilities for shipgenerated waste and cargo residues n.d.. 19.11.2015, OJ L 302, p. 99-102

Commission of the European Communities, COM (1998) 452 final, Explanatory Memorandum: Proposal for a Council Directive on Port Reception Facilities for Ship-Generated Waste and Cargo Residues. 98/0249 (SYN). 1998

Consolidated Guidance for Port Reception Facility Providers and Users. 2014, MEPC.1/Circ.834

de La Fayette L (1996) Access to Ports in International Law. Int J Marine Coastal Law 11(1):22

European Commission (2012) In: Directorate-General Environment (ed) Guidance on the interpretation of key provisions of directive 2008/98/EC on waste, p 74

European Commission (2016a) COM (2016) 168 final REFIT Evaluation of Directive 2000/59/EC on port reception facilities for shipgenerated waste and cargo residues. In: Report from the Commission to the European Parliament and the Council, p 15

European Commission. REFIT: Making EU lighter, simpler, and less costly. 2016b; Available from: http://ec.europa.eu/smartregulation/docs/refit_brochure_en.pdf. [cited 201719 April]

European Commission COM (2018) 33 final Proposal for a Directive of the European Parliament and of the council on port reception facilities for the delivery of waste from ships 2018

European Commission, Roadmap Inception Impact Assessment: REFIT Revision of EU Directive 2000/59/EC on port reception facilities for ship-generated waste and cargo residues 2015

European Maritime Safety Agency (EMSA), Horizontal Assessment Report - Port Reception Facilities (Directive 2000/59/EC) 2010

Fisher E, Lange B, Scotford E (2013) Environmental Law: Text, Cases, and Materials. Oxford University Press, Great Britain

Frank, V., The European Community and Marine Environmental Protection in The International Law of the Sea: Implementing Global Obligations at the Regional Level. 2007, The Netherlands: Martinus Nijhoff Publishers. xxi, 480 s

International Maritime Organization (IMO) (2016) Port Reception Facilities - How to do it, in Inadequacy of Reception Facilities Updated version of the draft Manual on Port reception facilities. MEPC 69/11, London

Krämer L (2015) EU Environmental Law, 8th edn. Sweet \& Maxwell, Great Britain

Marten B (2014) Port State Jurisdiction and the Regulation of International Merchant Shipping. Hamburg studies on maritime affairs. Springer, Switzerland

Mitchell RB (1994) Intentional oil pollution at sea: environmental policy and treaty compliance. Massachusetts Institute of Technology Press, England

Moules R (2011) Environmental Judicial Review. Hart Publishing Ltd, Great Britain

Panteia and PWC (2015) Ex-Post evaluation of Directive 2000/59/EC on port reception facilities for ship-generated waste and cargo residues (Final Report). European Commission, Brussels

Port of Felixstowe, Waste Management Plan S002-R11. 2016

Port of Helsinki, West Harbour Waste Management Plan. 2019

Ramboll (2012) Final report: EMSA Study on the delivery of ship-generated waste and cargo residues to port reception facilities in EU ports, in EMSA/OP/06/2011. European Maritime Safety Agency (EMSA), Copenhagen

Rayfuse R (2016) Principles of international environmental law applicable to waste management. In: Kummer K, Ziegler AR, Baumgartner J (eds) Waste management and the green economy: law and policy. Edward Elgar Publishing, Cheltenham Reddish M (1994) ECJ case report: case C-236. Eur Environ Law Rev 3(10):307-310

Ringbom H (2008) The EU Maritime Safety Policy and International Law. Martinus Nijhoff Publishers, Leiden

Rotterdam, P.o., Port Waste Handling Plan for Rotterdam-Rijnmond Port Region. 2018

Rue, C.D.L. and C.B. Anderson, Shipping and the Environment: Law and Practice. 2 2009: Informa Law 1247

Svaetichin I, Inkinen T (2017) Port waste Management in the Baltic Sea Area: a four port study on the legal requirements, Processes and Collaboration. Sustain 9(699):1-17

Swedish Transport Agency, Application for exemption from mandatory delivery of waste from ships in scheduled traffic. 2019

Tan AK-J (2006) Vessel-source marine pollution: the law and politics of international regulation. Cambridge University Press, Cambridge

van Calster G (2015) EU Waste Law. 2. Oxford University Press, USA, p 391

Vaneeckhaute C, Fazli A (2020) Management of ship-generated food waste and sewage on the Baltic Sea: a review. Waste Manag 102:12-20

Wilewska-Bien M, Granhag L, Andersson K (2018) Pathways to reduction and efficient handling of food waste on passenger ships: from Baltic Sea perspective. Environ Dev Sustain 22:217-230

Zuin S, Belac E, Marzi B (2009) Life cycle assessment of ship-generated waste management of Luka Koper. Waste Manag 29: 3036-3046

\section{Publisher's Note}

Springer Nature remains neutral with regard to jurisdictional claims in published maps and institutional affiliations. 